\title{
ARTIKELEN
}

\section{Het Tijdschrift voor Criminologie in de eerste twee decennia van de 21 e eeuw: een kwantitatieve (netwerk)analyse}

\author{
Arjan Blokland
}

Voortbouwend op eerdere kwantitatieve analyses door Rovers (1999) en Rovers en Boers (2009) geeft dit artikel een cijfermatig overzicht van de in de afgelopen 60 jaar in het Tijdschrift voor Criminologie verschenen bijdragen, met een nadruk op de periode 1999-2018. De eerste generatie Nederlandse criminologen begint langzaam uit beeld te raken. Mannen domineren nog steeds de top 25 meest publicerende auteurs. Een sociale netwerkanalyse van het samenwerkingsnetwerk van TvC-auteurs laat enerzijds veel alleen publicerende auteurs, maar anderzijds ook een grote component van aan elkaar te linken auteurs zien.

\section{Inleiding}

Reeds twee keer eerder werd een jubileumnummer van het Tijdschrift voor Criminologie $(\mathrm{TvC})$ opgeluisterd door een artikel dat nu eens niet een criminologisch onderwerp bij de hoorns vatte, maar het tijdschrift zelf - als belangrijkste wetenschappelijke forum in de Nederlandstalige criminologie (Rovers, 1999) - als onderzoeksobject koos. In de tien jaar na het verschijnen van het laatste overzicht (Rovers \& Boers, 2009) is er echter veel veranderd. Zo publiceert het tijdschrift Panopticon inmiddels regelmatig bijdragen van zowel Vlaamse als Nederlandse auteurs, verschijnt sinds 2011 het Tijdschrift over Cultuur \& Criminaliteit en verbrak de Nederlandse Vereniging voor Criminologie recent nog de officiële band tussen de vereniging en het tijdschrift, waardoor de status van officieuze spreekbuis van criminologisch Nederland niet zomaar meer door iedereen aan TvC zal worden toegekend. In termen van omvang echter, blijft $\mathrm{TvC}$ ook de laatste jaren nog onbetwist 'de grootste' en op basis daarvan alleen al een belangrijke graadmeter voor wat er speelt binnen de Nederlandstalige criminologie.

$\mathrm{TvC}$ werd voor het eerst cijfermatig in beeld gebracht ter gelegenheid van het 40jarig jubileum (Rovers, 1999). Rovers telde in die periode 212 nummers met samen 854 gepubliceerde artikelen. Hij richtte zich op het beschrijven van de auteurs (aantal per artikel, geslacht, discipline, instituut en hoeveelheid publicaties), de inhoud van de artikelen (type artikel, object van studie en thema) en de literatuurverwijzingen (aantal, time lag, meest geciteerde auteurs, tijdschriften, boeken en artikelen). Rovers (1999) concludeert onder meer dat TvC steeds minder een mannenbolwerk wordt en dat psychiaters zijn vervangen door sociaal wetenschappers. 
De cijfers zijn volgens Rovers $(1999,137)$ vooral geschikt - of bedoeld - om bestaande (voor)oordelen over het tijdschrift kritisch tegen het licht te houden. Maar hoewel geen interpretaties worden toegevoegd, kan uit de gekozen analyses en het in het overzicht gebezigde taalgebruik wel het een en ander worden afgeleid over wat er zoal in de wandelgangen over $\mathrm{TvC}$ werd gefluisterd of, bij gelegenheid, geroepen. Zo constateert Rovers $(1999,126)$ dat de opkomst van 'volleybalteams' in de door hem bestudeerde periode beperkt is gebleven: vier of meer auteurs per artikel blijft een uitzondering, al neemt het percentage artikelen geschreven door meerdere auteurs wel toe. Ook wanneer Rovers $(1999,125)$ spreekt over 'inteelt' onder TvC-auteurs klinkt dit weinig positief. In de vier decennia tussen 1959 en 1999 varieert de 'inteeltcoëfficiënt', oftewel de ratio van het totaal aantal auteurs en het totaal aantal unieke auteurs, ${ }^{1}$ tussen de 1,7 en 2,1 . In de jaren zeventig is het aantal unieke auteurs in vergelijking met het totaal aantal auteurs kleiner dan in de overige perioden, hetgeen erop duidt dat de pagina's van $\mathrm{TvC}$ in die perioden gevuld worden door een relatief kleine groep auteurs.

Een 'hitlijstje' met meest publicerende auteurs kan in een dergelijk overzicht niet ontbreken. Wouter Buikhuisen behoort tot de meest publicerende auteurs in de jaren zestig en zeventig, Riekent Jongman staat (het) hoog(st) op de lijst in de jaren zeventig en tachtig. De jaren tachtig en negentig zijn de decennia van Gerben Bruinsma. ${ }^{2}$ Tussen 1999 en 2008 wordt de hitlijst aangevoerd door respectievelijk Paul Nieuwbeerta (15 artikelen), Catrien Bijleveld (14 artikelen) en Arjan Blokland (9 artikelen). Over de volledige periode tussen 1959 en 2008 wordt de lijst aangevoerd door Riekent Jongman (39 artikelen), Gerben Bruinsma (33 artikelen) en Wouter Buikhuisen (31 artikelen).

\section{Operationalisaties}

Rovers (1999) baseert zijn cijfermatig overzicht van 40 jaar $\operatorname{TvC}$ op 'artikelen, discussie-artikelen, replieken en duplieken' (p. 124). De inventarisatie van Rovers en Boers (2009) beperkt zich tot 'bijdragen aan het tijdschrift die een wetenschappelijk karakter hebben' (p. 116). Ook deze auteurs laten inleidingen van themanummers in beginsel buiten beschouwing, maar signaleren wel de trend dat deze inleidingen steeds vaker meer om het lijf hebben dan louter een 'inleiding van de overige bijdragen in het (thema)nummer'. Uit een voetnoot blijkt dat 'substantiële inleidingen' daarom wel als artikel zijn meegeteld.

Kronieken, bijdragen waarin een expert een overzicht geeft van de belangrijkste ontwikkelingen in een aanpalende discipline, of binnen een specifiek deelgebied van de criminologie, vormen inmiddels een vaste waarde binnen het tijdschrift. Sinds enkele jaren verschijnen ook 'onderzoeksnotities', bijdragen met een meer methodologisch karakter en korter dan reguliere artikelen. Samen met substantiële inleidingen van themanummers brengen deze 'nieuwe' publicatievormen

1 Wat neerkomt op het gemiddeld aantal artikelen per auteur in die periode.

2 Frans Willem Winkel is de meest publicerende auteur in de jaren tachtig, maar publiceert slechts één artikel in de jaren negentig. 
belangrijke wetenschappelijke kennis over. In de huidige analyses worden daarom naast artikelen, discussieartikelen, replieken en duplieken, ook inleidingen, kronieken en onderzoeksnotities als 'bijdragen' meegeteld.

Rovers (1999) en Rovers en Boers (2009) beperkten zich in hun analyses tot respectievelijk de eerste vier en de eerste drie auteurs van een artikel. Eventuele overige auteurs worden door hen buiten beschouwing gelaten. Voor het huidige overzicht zijn alle auteurs meegeteld. Overeenkomstig eerdere analyses is ook in de huidige analyses geen gewicht toegekend aan opeenvolgende auteurs. Alle auteurs, ongeacht hun positie in de auteursvolgorde, tellen dus even zwaar mee. Verschillen in zowel het type meegenomen bijdragen als het aantal meegenomen auteurs maken dat de resultaten van de huidige analyses voor de periode 1999-2008 kunnen afwijken van die genoemd in Rovers en Boers (2009). Waar relevant is dit weergegeven in de hier gepresenteerde tabellen en figuren.

\section{Resultaten}

Tussen 1999 en 2018 verschijnt het tijdschrift vier keer per jaar. In totaal verschijnen in die periode 766 unieke bijdragen, (mee)geschreven door 598 unieke auteurs. Voor de periode 1999 en 2008 komt de ratio van het totaal aantal auteurs en het aantal unieke auteurs - Rovers' (1999) 'inteelt'-ratio - uit op 2,0. In de daaropvolgende tien jaar komt die ratio op 1,9. Vergelijken we deze cijfers met de 'inteeltcoëfficiënt' voor de overige tienjaarsperioden sinds de afsplitsing van TvC (Rovers, 1999: tabel 2, p. 125), dan lijkt de groep TvC-auteurs de afgelopen tien jaar weer wat diverser te worden.

De door Rovers en Boers (2009) geconstateerde trend in het toenemende aantal auteurs per bijdrage lijkt zich in de afgelopen tien jaar te hebben voortgezet. Figuur 1 geeft voor de afgelopen decennia weer welk percentage van de gepubliceerde bijdragen een, twee of drie of meer auteurs had. Door het opnemen van kronieken - die vaak (maar niet altijd) door één auteur worden geschreven - ligt het aantal bijdragen met één auteur onder de operationalisatie van het huidige onderzoek hoger dan dat onder eerdere operationalisaties. Desalniettemin blijft er sprake van een daling in het aantal bijdragen met één auteur, die voor een groot deel op conto komt van een stijging van het aantal bijdragen met drie of meer auteurs. Mogelijk wordt dit veroorzaakt door het toenemende empirische karakter van de Nederlandstalige criminologie. Waar discussiestukken makkelijker door één auteur kunnen worden geschreven, behelst een empirisch artikel vaak een samenwerking tussen meerdere onderzoekers. Ook kan het opnemen van inleidende artikelen - die door de voltallige themaredactie worden geschreven - hier mede debet aan zijn. Een eventuele angst voor bijdragen 'geschreven' door hele 'volleybalteams' lijkt vooralsnog ongegrond; het aantal bijdragen met zes of meer auteurs blijft in de periode 1999-2018 op één hand te tellen. 


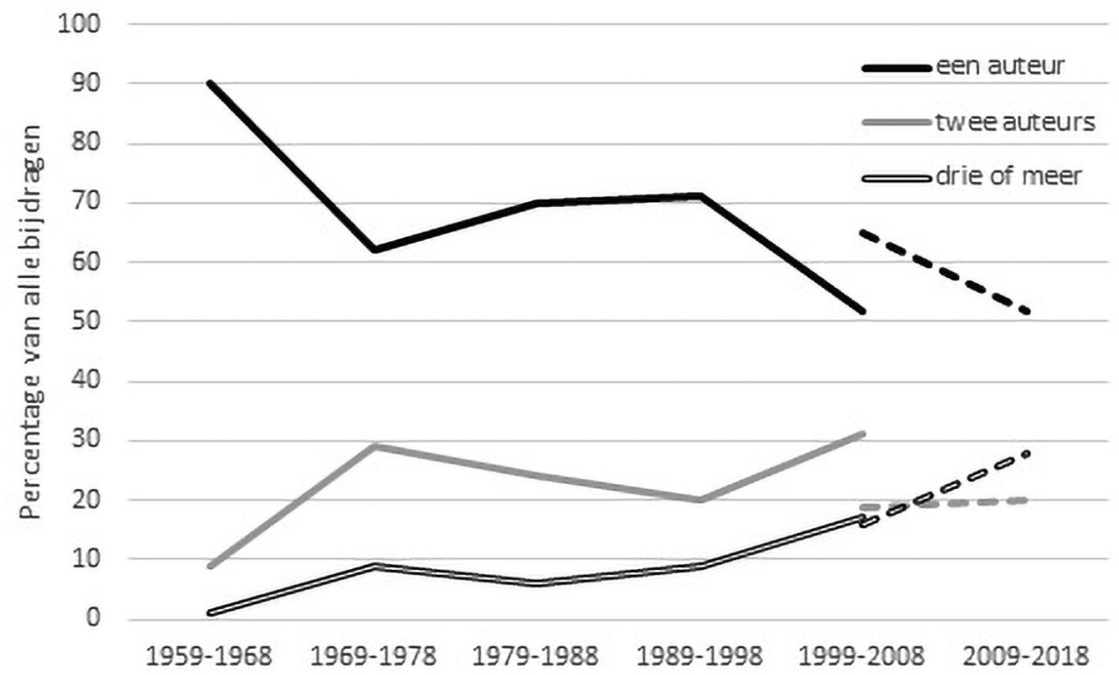

Figuur 1 Percentage bijdragen naar aantal auteurs per bijdrage, per decennium

\section{Veelschrijvers}

Tabel 1 geeft een overzicht van de top 25 meest publicerende auteurs over de afgelopen 60 jaar. De tweede en derde kolom geven de rangvolgorde van deze auteurs op basis van respectievelijk het aantal bijdragen (kolom 2) en het aantal geschreven pagina's (kolom 3 ) in de eerste 50 jaar. Omdat elke afzonderlijke bijdrage voorafgaand aan publicatie door de redactie en externe reviewers op toegevoegde waarde wordt getoetst, terwijl de lengte van een bijdrage een meer ondergeschikte rol speelt in de beoordeling, is er hier gekozen voor een rangordening op basis van het aantal bijdragen. Anders dan in de eerdere overzichten is in geval van een gelijk aantal bijdragen de rangordening van volgende auteurs doorgeteld: na een gedeelde twaalfde plaats volgt hierdoor de veertiende en niet de dertiende plaats. Na de namen van de betreffende auteurs volgt het totaal aantal gepubliceerde bijdragen tot nu toe en het aantal bijdragen gepubliceerd in de tien jaar tussen 1999-2008 en 2009-2018. Figuur 2 visualiseert de belangrijkste dalers en stijgers in de huidige hitlijst ten opzichte van die van tien jaar geleden.

Riekent Jongman mag zich vooralsnog de meest publicerende auteur in TvC blijven noemen. Hij voert met 39 bijdragen de lijst aan. Hij wordt op de voet gevolgd door Paul Nieuwbeerta, die tot nu toe (mede)auteur was van 37 artikelen. Gerben Bruinsma bezet met 35 artikelen de derde plaats. Op nummer 4 vinden we de eerste en enige vrouw in deze top 25: Catrien Bijleveld met 33 bijdragen. De eerstvolgende veel schrijvende vrouwen (niet in tabel 1) in de periode 1999-2018, Anja Dirkzwager (13 bijdragen) en Janine Janssen (11 bijdragen), vallen nog (ruim) buiten de algehele top 25. De top 3 veelschrijvers in de periode 2009-2018 wordt gevormd door achtereenvolgens: Paul Nieuwbeerta (20 bijdragen), Arjan Blokland (16 bijdragen) en Catrien Bijleveld (13 bijdragen). 
Tabel 1 Top 25 van de meest publicerende auteurs over 60 jaar, vergeleken met de top 25 over de eerste 50 jaar (aantal bijdragen totaal, over 1999-2008 en over 2009-2018; rangorde cijfers op basis van gepubliceerde bijdragen)

\begin{tabular}{|c|c|c|c|c|c|c|}
\hline $\begin{array}{l}\text { Rang } \\
60 \text { jaar } \\
\text { artike- } \\
\text { len }\end{array}$ & $\begin{array}{l}\text { Rang } \\
\text { eerste } \\
50 \text { jaar } \\
\text { artike- } \\
\text { len }{ }^{\mathrm{a}}\end{array}$ & $\begin{array}{l}\text { Rang } \\
\text { eerste } \\
\mathbf{5 0} \text { jaar } \\
\text { pagina's }\end{array}$ & Auteur & $\begin{array}{l}\text { I959-20I8 } \\
\text { aantal } \\
\text { artikelen }\end{array}$ & $\begin{array}{l}1999-2008 \\
\text { aantal } \\
\text { artikelen }^{\text {b }}\end{array}$ & $\begin{array}{l}2009-20 \text { I8 } \\
\text { aantal } \\
\text { artikelen }\end{array}$ \\
\hline 1 & 1 & 1 & Jongman (Riekent W.) & 39 & - & - \\
\hline 2 & 10 & 6 & Nieuwbeerta (Paul) & 37 & 16 & 20 \\
\hline 3 & 2 & 3 & Bruinsma (Gerben J.N.) & 35 & 8 & I \\
\hline 4 & 7 & 7 & Bijleveld (Catrien C.J.H.) & 33 & 17 & 13 \\
\hline 5 & 3 & 2 & Buikhuisen (Wouter) & 31 & - & - \\
\hline 6 & 4 & 5 & Bunt (Henk G. van de) & 30 & 8 & 5 \\
\hline 7 & 5 & 4 & Dijk (Jan J.M. van) & 27 & 2 & 3 \\
\hline 8 & 15 & 14 & Blokland (Arjan A.J.) & 26 & 10 & 16 \\
\hline 9 & 15 & 12 & Haan (Willem J.M. de) & 24 & 8 & 3 \\
\hline 10 & 15 & 20 & Kleemans (Edward R.) & 20 & 12 & 6 \\
\hline II & 10 & 8 & Leuw (Ed) & 19 & 2 & I \\
\hline 12 & 6 & 9 & Timmerman (Harrie) & 18 & - & - \\
\hline 12 & 7 & 11 & Nijboer (Jan A.) & 18 & 2 & - \\
\hline 14 & 7 & 14 & Bianchi (Herman) & 17 & - & - \\
\hline 14 & 17 & 16 & Korf (Dirk Jan) & 17 & 9 & 4 \\
\hline 14 & 12 & 17 & Fijnaut (Cyrille J.C.F.) & 17 & 2 & I \\
\hline 14 & - & - & Laan (Peter H. van der) & 17 & 14 & 3 \\
\hline 18 & 14 & 10 & Winkel (Frans Willem) & 16 & 2 & - \\
\hline 19 & 12 & 13 & Weringh (Jac. van) & 15 & - & - \\
\hline 20 & 20 & 19 & Weerman (Frank M.) & 15 & 8 & 5 \\
\hline 21 & 20 & 21 & Bernasco (Wim) & 14 & 10 & 3 \\
\hline 21 & 17 & 23 & Fiselier (Jan P.S.) & 14 & 3 & I \\
\hline 21 & - & - & Elffers (Henk) & 14 & 10 & 4 \\
\hline 21 & - & - & Huisman (Wim) & 14 & 7 & 7 \\
\hline 21 & - & - & Wilsem (Johan van) & 14 & 3 & 11 \\
\hline
\end{tabular}

a Anders dan in Rovers en Boers (2009) is er in deze tabel voor gekozen het rangnummer door te nummeren na twee of meer auteurs met dezelfde score. Bijvoorbeeld: in de ranglijst van het aantal gepubliceerde artikelen gerekend over de afgelopen 60 jaar delen Timmerman en Nijboer de twaalfde plaats, Bianchi staat vervolgens op plaats 14.

b Deze kolom wijkt iets af van die in Rovers en Boers (2009) omdat hier gekozen is voor een ruimere definitie van 'artikel'.

Een vergelijking met de top 25 van tien jaar geleden geeft zicht op de belangrijkste stijgers en dalers in de lijst. Herman Bianchi en Jac. van Weringh 


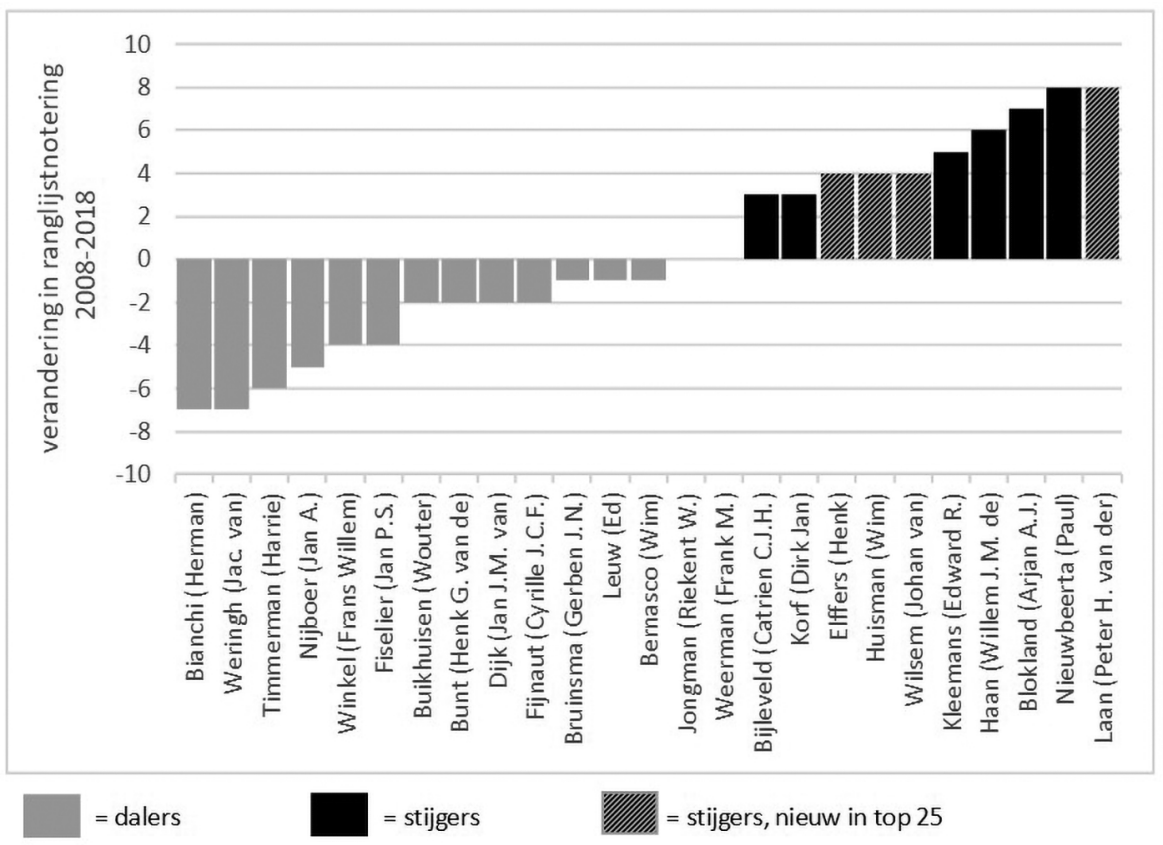

Figuur 2 Stijgers en dalers in de top 25 van de meest publicerende auteurs over 60 jaar

zijn, met een verlies van zeven plaatsen, de grootste dalers. Paul Nieuwbeerta en Peter van der Laan zijn de grootste stijgers, met dit verschil dat die laatste in 2009 nog geen deel uitmaakte van de top 25 meest in het tijdschrift publicerende auteurs. Gerekend vanaf plaats 25 is zijn binnenkomst op plaats 14 een stijging van acht plaatsen.

Vele handen maken misschien licht werk. Figuur 3 geeft daarom antwoord op de vraag: hebben veelschrijvers gemiddeld ook meer coauteurs? Het antwoord voor de periode 1999-2018 luidt ontkennend. Hoewel de balken in figuur 3 een lichte stijging laten zien met het toenemen van het aantal publicaties, geven de foutenbalken aan dat er onder auteurs met minder bijdragen een grote spreiding bestaat in het aantal coauteurs.

\section{Samenwerkingsnetwerk}

Behalve ter beoordeling van de prestaties van individuele auteurs, kunnen gegevens over (co)auteurschap ook worden gebruikt om een beeld te schetsen van een 
6

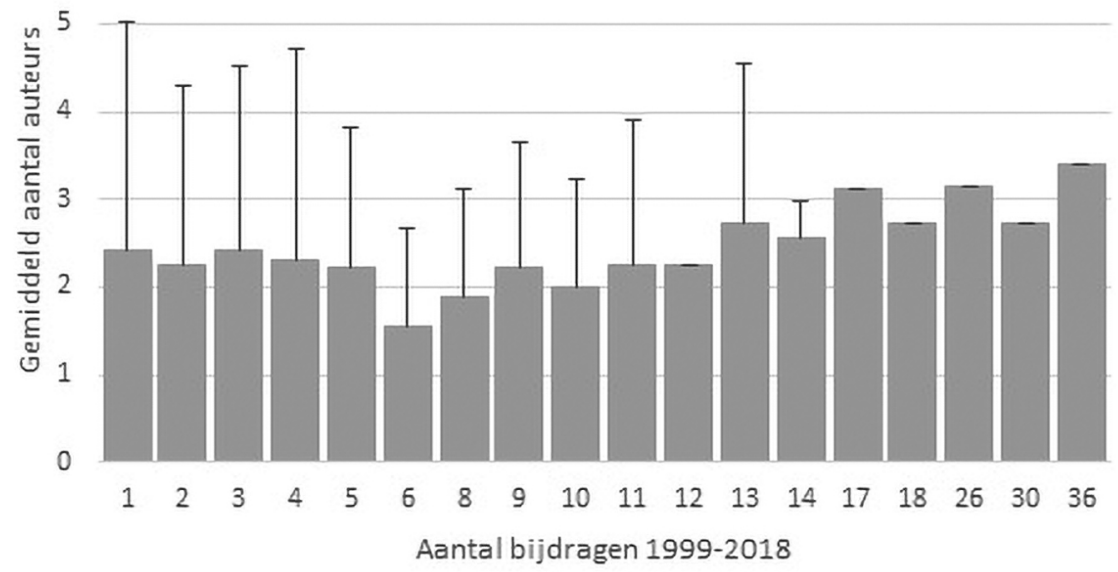

Figur 3 Gemiddeld aantal auteurs per bijdrage naar aantal bijdragen per auteur in de periode 1999-2018

compleet wetenschapsgebied - in dit geval de Nederlandstalige criminologie. ${ }^{3}$ Door de samenwerkingsverbanden tussen TvC-auteurs in kaart te brengen met behulp van sociale netwerkanalyse kan een inkijkje in de Nederlandstalige criminologie worden verkregen, dat verborgen blijft bij het gebruik van traditionele beschrijvende statistiek. In een samenwerkingsnetwerk worden auteurs weergegeven als nodes - cirkels - en coauteurschappen als edges - een lijn die twee nodes met elkaar verbindt. Een samenwerkingsnetwerk op basis van coauteurschap is ongericht; er wordt geen rekening gehouden met wie de samenwerking initieerde. De navolgende analyses betreffen de twintig jaar sinds 1999. Auteurs zijn met elkaar verbonden als ze ten minste één gezamenlijke publicatie in TvC hadden in de periode 1999-2018. In een samenwerkingsnetwerk wordt het aantal unieke coauteurs dat een auteur heeft (het aantal edges dat vanuit een bepaalde node vertrekt) aangeduid met de term degree. Een samenwerkingsnetwerk kan ten slotte bestaan uit een of meerdere componenten. Een netwerkcomponent is een gedeelte van een netwerk waarin alle auteurs direct of indirect met elkaar verbonden zijn. ${ }^{4}$ Voor de analyses hierna werd gebruik gemaakt van het programma Pajek (De Nooy e.a., 2018).

Gemiddeld hebben auteurs in het samenwerkingsnetwerk 2,57 coauteurs. Figuur 4 geeft de verdeling van het aantal coauteurs. Van de 598 auteurs heeft 24,7 procent $(n=145)$ geen enkele coauteur in de periode 1999-2018. Nog eens 22,4 pro-

3 Met hierbij nog eens de kanttekening dat het Tijdschrift voor Criminologie de afgelopen tien jaar concurrentie heeft gekregen van andere Nederlandstalige criminologische tijdschriften. Het geschetste beeld van de 'Nederlandstalige criminologie' is daarom wellicht onvolledig, of zelfs enigszins vertekend.

4 Zie onder meer Borgatti en collega's (2013) voor een uitgebreide inleiding in de begrippen en methoden van sociale netwerkanalyse. 


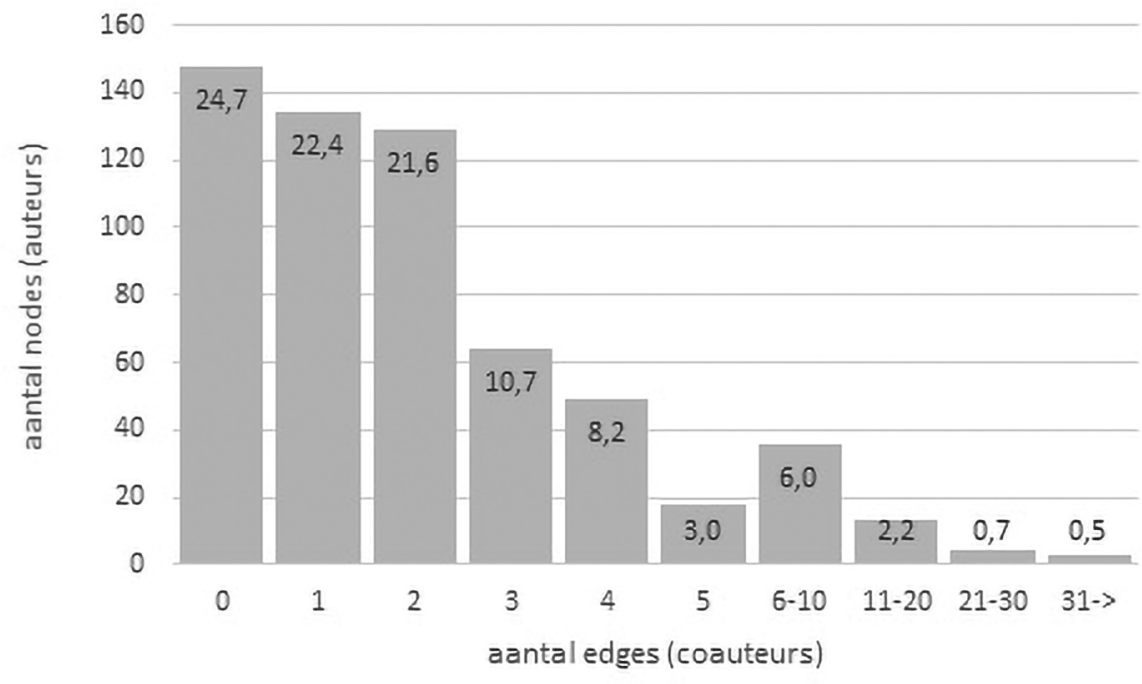

Figur 4 Verdeling aantal nodes (auteurs) per aantal edges (coauteurs) in de periode 1999-2018

cent $(n=134)$ heeft slechts één coauteur. Nog geen 10 procent van de TvC-auteurs heeft met meer dan vijf verschillende coauteurs gepubliceerd.

Wanneer we de 148 singletons - auteurs zonder coauteurs - weglaten, bestaat het complete samenwerkingsnetwerk van TvC-auteurs voor de periode 1999-2018 uit 61 afzonderlijke componenten. De grootste component bestaat uit 290 auteurs (48,5 procent van het totaal aantal unieke auteurs) die allemaal direct of indirect via coauteurschappen van TvC-artikelen aan elkaar te linken zijn. De overige componenten bestaan uit ten hoogste zeven auteurs die wel met elkaar, maar niet met auteurs uit de grootste component publiceerden.

Binnen de grootste component van 290 auteurs valt nader onderscheid te maken in zogenaamde communities - groepjes auteurs die vooral met elkaar publiceren. De aanwezigheid van communities kan erop duiden dat auteurs geneigd zijn te publiceren met auteurs die veel met hen gemeen hebben, bijvoorbeeld het onderwerp van hun onderzoek, hun disciplinaire achtergrond, of de universiteit waar zij werkzaam zijn. Samenwerking buiten de eigen community bevordert doorgaans de interdisciplinariteit, leidt tot innovatieve oplossingen en ideeën, en kan de kwaliteit van het onderzoek verbeteren. Figuur 5 geeft de grootste component van het samenwerkingsnetwerk van TvC-auteurs in de periode 1999-2018 weer. Modulariteit in het netwerk is hier berekend met de Louvain-methode (De Nooy e.a., 2018, 132-135). De grijstinten waarin de verschillende nodes zijn weergegeven, verwijst naar de community waarin zij zijn ingedeeld. In het samenwerkingsnetwerk van TvC-auteurs kunnen veertien communities worden onderschei- 
den. In de weergave van het netwerk in figuur 5 zijn de verschillende communities zo veel mogelijk visueel onderscheiden.

Sommige communities laten zich eenvoudig duiden, bijvoorbeeld de victimologen (A) boven in de figuur. Zij publiceren vooral met elkaar en publiceren relatief weinig met andere auteurs in het netwerk. Andere communities concentreren zich rondom een enkele, herhaald in $\mathrm{TvC}$ publicerende auteur. Dit is bijvoorbeeld het geval bij een aantal auteurs van het WODC (B), de Politieacademie (C; D) en Avans Hogeschool (D). Andere communities lijken zich vooral te concentreren rondom een bepaald onderwerp, zoals detentie (E), onderzoeksmethodologie (F), ontwikkelingscriminologie van kinderen en adolescenten $(G)$, of forensische orthopedagogiek $(\mathrm{H})$ (respectievelijk rechtsonder, midden onder en linksonder). In de community helemaal links in de figuur zien we relatief veel Vlaamse auteurs (J). De communities in het midden kenmerken zich vooral door hun grote verwevenheid met andere communities. Auteurs in deze communities publiceren veel met elkaar, maar ook met anderen. Het is daarom moeilijk om deze communities van een eenduidig label te voorzien. ${ }^{5}$ De grote hoeveelheid edges tussen communities $\mathrm{G}$ en $\mathrm{H}$ en de communities in het midden van het samenwerkingsnetwerk ten slotte, geven aan dat de auteurs uit de ontwikkelingscriminologie en forensisch orthopedagogische hoek sterker zijn ingebed in de kern van het samenwerkingsnetwerk dan bijvoorbeeld de victimologen. Ook de Vlaamse auteurs zijn via veel coauteurschappen verbonden met de kern van het samenwerkingsnetwerk.

\section{Afscheid van een generatie}

Ondanks de veranderingen van de afgelopen periode kiest een grote groep auteurs het Tijdschrift voor Criminologie nog steeds als podium. TvC blijft hiermee een belangrijke afspiegeling vormen van het Nederlandstalig criminologisch onderzoek, al doet de komst van (ver)nieuw(d)e tijdschriften binnen het Nederlands taalgebied, zoals Panopticon en het Tijdschrift over Cultuur \& Criminaliteit, wellicht wat af aan de representativiteit.

Rovers en Boers (2009) signaleerden een trend naar een toenemend aantal auteurs per artikel. Deze trend lijkt zich ook de afgelopen tien jaar te hebben voortgezet, al lijkt het doemscenario van 'volleybalteams' of erger vooralsnog uit te blijven. Mogelijk tekent zich in het toenemend aantal auteurs per bijdrage de verschuiving af van een opiniërende en normatieve naar een empirische discipline. Empirisch onderzoek - dataverzameling, analyse, verslaglegging - is nu eenmaal in veel gevallen een 'teamsport'. De door Rovers (1999) geconstateerde machtswisseling tussen juristen en sociaal wetenschappers - die tot op de dag van vandaag lijkt voort te duren - past bij een dergelijke interpretatie.

Verschuivingen in de top 25 meest publicerende auteurs geven aan dat de Nederlandse criminologie afscheid begint te nemen van de generatie criminologen van het eerste uur. Vijf van de top 25 meest publicerende auteurs tot 2009 publiceer-

5 Daarnaast resteren nog twee kleine communities (respectievelijk vier en acht auteurs), die sterk overlappen met andere communities (respectievelijk J en D/G). 


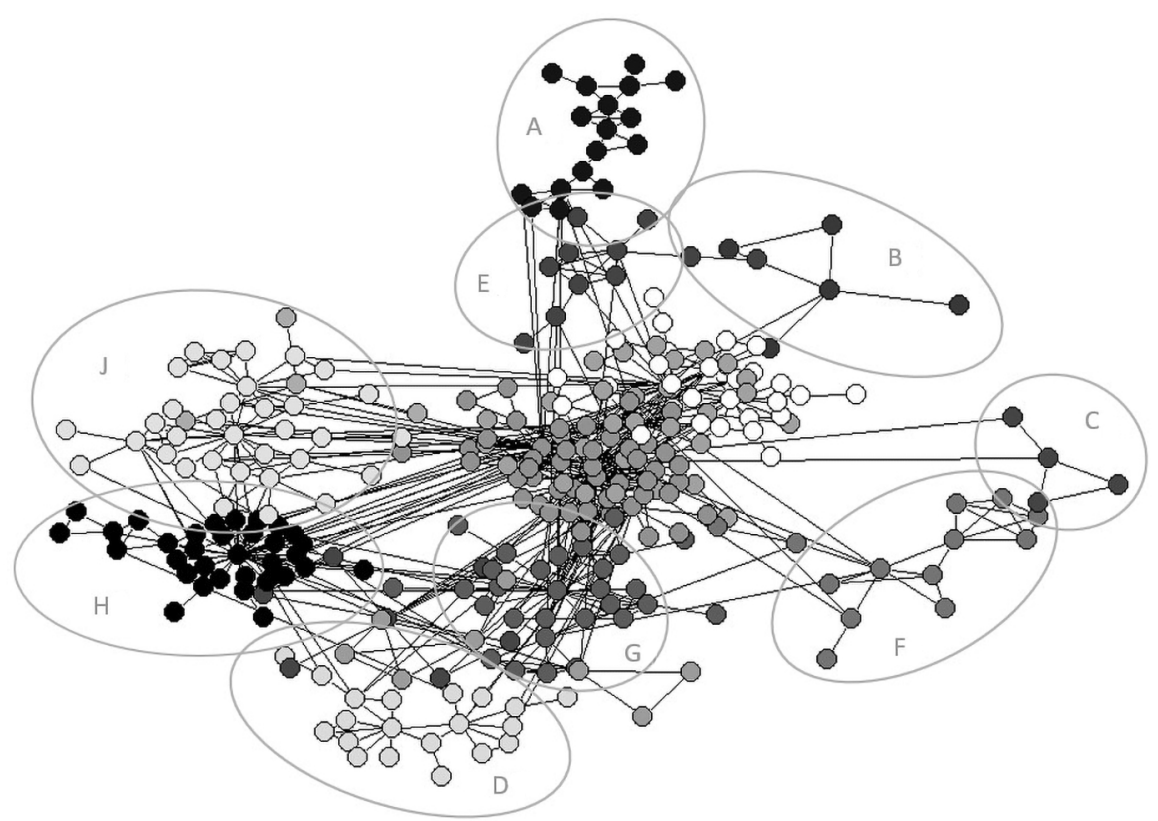

Figuur 5 Visualisatie van de grootste component van het samenwerkingsnetwerk van TvC-auteurs voor de periode 1999-2018, met onderscheid naar Louvain-communities

den de afgelopen twintig jaar niet meer in het tijdschrift: zij zijn met emeritaat, pensioen of zelfs overleden. Veel van de grootste stijgers hebben nog een aantal jaren voor de boeg, waardoor de ranglijst de komende tien jaar ongetwijfeld een nog grotere verschuiving naar een jongere, productievere (in termen van het aantal publicaties) generatie zal gaan laten zien.

In 1999 concludeerde Rovers nog dat TvC steeds minder een mannenbolwerk werd. Analyses van de meest publicerende auteurs over de afgelopen twintig jaar en de belangrijkste stijgers in de top 25 over de afgelopen 60 jaar laten echter zien dat binnen de Nederlandstalige criminologie de emancipatoire inhaalrace, althans voor zover het het aantal bijdragen per auteur betreft, nog verre van gelopen is. Veelschrijvers zijn - net als veelplegers overigens - nog steeds disproportioneel vaak van het mannelijk geslacht.

Een belangrijke kanttekening is hier echter op zijn plaats. De beschikbare tijd en informatie voor het schrijven van dit artikel noopte tot het maken van keuzes. De focus op het aantal bijdragen en niet op de inhoud van die bijdragen of de verwijzingen in en naar die bijdragen was daarvan misschien wel de belangrijkste. Als maat voor impact op het Nederlands criminologisch denken, het criminaliteitsbeleid of het criminologieonderwijs (om maar eens drie gebieden van mogelijke invloed te noemen) schiet het aantal publicaties in één tijdschrift, of überhaupt het aantal publicaties van een bepaalde auteur, overduidelijk tekort. 


\section{Halfleeg of halfvol?}

Interessanter is daarom wellicht de visualisatie van de samenwerkingsverbanden tussen de verschillende TvC-auteurs. Op basis hiervan kunnen met enige voorzichtigheid conclusies getrokken worden over het huidige criminologisch landschap in Nederland en Vlaanderen.

Bijna de helft van de TvC-auteurs in de periode 1999-2018 heeft geen of slechts één coauteur. Voor veel van hen is een publicatie in $\mathrm{Tv} C$ slechts een eenmalige gebeurtenis. Mogelijk betreft het hier student-auteurs die hun masterthesis omwerkten tot artikel, maar na hun afstuderen een carrière buiten de wetenschap begonnen, of aio's die na hun promoveren overstapten naar de overheid of het bedrijfsleven. Met de nadruk die sinds de eeuwwisseling wordt gelegd op het publiceren in internationale toptijdschriften - bijvoorbeeld om in aanmerking te kunnen komen voor NWO-financiering - kan het ook zijn dat academisch onderzoekers er in toenemende mate voor kozen alleen nog maar in het Engels te publiceren.

Een meer optimistische kijk op samenwerking binnen de Nederlandstalige criminologie benadrukt dat, de eerste twee decennia van de 21 e eeuw in ogenschouw nemend, bijna de helft van de TvC-auteurs met elkaar verbonden kan worden in een groot samenwerkingsnetwerk. Dit betekent dat er sprake is van informatie-uitwisseling tussen deze auteurs en dat zij direct of indirect kunnen profiteren van elkaars kennis en expertise. Dit samenwerkingsnetwerk overspant diverse onderzoeksonderwerpen, -methoden en -instituten en vormt daarmee de ruggengraat van de Nederlandstalige criminologie.

Hoewel deelname aan het internationale criminologische discours de kwaliteit van de Nederlandstalige criminologie ongetwijfeld ten goede is gekomen, kunnen verschraling en versnippering van de nationale criminologische kennis hiervan een ongewenste keerzijde zijn: slechts weinig beleidsmakers zullen systematisch de internationale literatuur bijhouden op zoek naar voor de Nederlandse context relevante inzichten. Het enorme aantal en de verregaande specialisatie van de Engelstalige criminologische tijdschriften maken dat zelfs voor academici het internationale werk van Nederlandse of Vlaamse collega's soms verborgen blijft. $\mathrm{Nu}$ de bakens van academische normering zich echter voorzichtig lijken te verplaatsen en de nationale rol van onderzoekers en onderzoeksgroepen weer (meer) aandacht krijgt, ligt een toenemende samenhang van de Nederlandstalige criminologie mogelijk in het verschiet. De interdisciplinaire basis hiervoor blijkt in de afgelopen twintig jaar reeds in belangrijke mate gelegd. Het thans jubilerende Tijdschrift voor Criminologie biedt een uitgelezen podium waarop deze ontwikkelingen ook in de toekomst kunnen worden (blijven) uitgespeeld.

\section{Literatuur}

Borgatti, S.P., Everett, M.G. \& Johnson, J.C. (2013). Analyzing social networks. Los Angeles, CA: Sage. 
Nooy, W. de, Mrvar, A. \& Batagelj, V. (2018). Exploratory social network analysis with Pajek. Cambridge, UK: Cambridge University Press.

Rovers, B. (1999). Veertig jaar (Nederlands) Tijdschrift voor Criminologie in cijfers 1959-1998. Tijdschrift voor Criminologie, 41(2), 123-137.

Rovers, B. \& Boers, R. (2009). Vijftig jaar Tijdschrift voor Criminologie in cijfers. Wat gebeurde er de afgelopen tien jaar? Tijdschrift voor Criminologie, 51(2), 116-132. 